\section{Rooting of Rose Cuttings in Response to Foliar Applications of Auxin and Surfactant}

\author{
Eugene K. Blythe ${ }^{1}$, \\ Jeff L. Sibley ${ }^{2}$, Ken M. Tilt ${ }^{3}$, \\ and John M. Ruter ${ }^{4}$
}

ADDITIONAL INDEX WORDs. adventitious rooting, cutting propagation, Dip 'N Grow, IBA, indole-3-butyric acid, NAA, 1-naphthaleneacetic acid, K-IBA, K-NAA, Kinetic, root-promoting chemicals, Rosa 'Red Cascade', spray adjuvants, spray application

SuMMARY. In five experiments, singlenode cuttings of 'Red Cascade' miniature rose (Rosa) were treated with a basal quick-dip (prior to insertion into the rooting substrate) or sprayed to the drip point with a single foliar application (after insertion) of Dip 'N Grow [indole-3-butyric acid (IBA) + 1-naphthaleneacetic acid (NAA)], the potassium salt of indole-3-butyric acid (K-IBA), or the potassium salt of 1-naphthaleneacetic acid (K-NAA); a single foliar spray application of Dip 'N Grow with and without Kinetic surfactant; or multiple foliar spray applications of Dip 'N Grow. Spray treatments were compared with their respective basal quick-dip controls

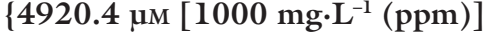
$\mathrm{IBA}+2685.2 \mu \mathrm{M}\left(500 \mathrm{mg} \cdot \mathrm{L}^{-1}\right) \mathrm{NAA}$, $4144.2 \mu \mathrm{M}\left(1000 \mathrm{mg} \cdot \mathrm{L}^{-1}\right) \mathrm{K}-\mathrm{IBA}$, or $\left.4458.3 \mu \mathrm{M}\left(1000 \mathrm{mg} \cdot \mathrm{L}^{-1}\right) \mathrm{K}-\mathrm{NAA}\right\}$. Cuttings sprayed with 0 to 246.0 $\mu \mathrm{M}\left(50 \mathrm{mg} \cdot \mathrm{L}^{-1}\right) \mathrm{IBA}+134.3 \mu \mathrm{M}(25$ $\left.\mathrm{mg} \cdot \mathrm{L}^{-1}\right) \mathrm{NAA}, 0$ to $207.2 \mu \mathrm{M}(50$

This research was supported in part by the Horticultura Research Institute, 1000 Vermont Avenue, NW, Suite 300, Washington, DC 20005 and by Dip 'N Grow, Inc., Clackamas, OR 97015. Mention of a trademark, proprietary product, or vendor does not constitute a guarantee or warranty nor does it imply the recommendation of the product by Auburn University to the exclusion of other products or vendors that also may be suitable.

${ }^{1}$ Research assistant; to whom reprint requests should be addressed. E-mail: blythek@auburn.edu

${ }^{2}$ Alumni associate professor.

${ }^{3}$ Professor, Department of Horticulture, Auburn University, AL 36849

${ }^{4}$ Professor, CPES, Department of Horticulture, University of Georgia, Tifton, GA 31793. $\left.\mathrm{mg} \cdot \mathrm{L}^{-1}\right) \mathrm{K}-\mathrm{IBA}$, or 0 to $222.9 \mu \mathrm{M}(\mathbf{5 0}$ $\left.\mathrm{mg} \cdot \mathrm{L}^{-1}\right) \mathrm{K}-\mathrm{NAA}$ resulted in rooting percentages, total root length, percent rooted cuttings with shoots, and shoot length similar to or less than control cuttings. Exceptions were cuttings sprayed with 0 to $2.23 \mu \mathrm{M}$ $\left(0.5 \mathrm{mg} \cdot \mathrm{L}^{-1}\right) \mathrm{K}-\mathrm{NAA}$, which exhibited shoot length greater than the control cuttings. Addition of $1.0 \mathrm{~mL} \cdot \mathrm{L}^{-1}$ (1000 ppm) Kinetic organosilicone surfactant to spray treatments resulted in greater total root length and shoot length. Repeated sprays (daily up to seven consecutive days) had no or negative effects on root and shoot development.

A uxins in liquid or powder (talc) forms are commonly used in commercial cutting propagation as root-promoting chemicals. Commercial formulations commonly contain IBA, NAA, or a combination of the two. Commercial products intended for dilution to the desired concentration for treating cuttings of specific crops are available as alcohol-based concentrates or watersoluble formulations (Hartmann et al., 2002).

Auxin solutions have traditionally been applied to the basal portion of cuttings, the site of subsequent root formation, by means of a quick dip or an extended basal soak (Hartmann et al., 2002). A quick dip is often the preferred method of applying liquid auxin formulations due to the advantages of economy, speed, ease of use, and uniformity of application and results. Other methods of auxin application have been investigated, including forced entry of auxins into cuttings using a vacuum, insertion of auxintreated objects (such as toothpicks) into the cutting base, immersion of cuttings in an auxin solution for varying lengths of time, and treatment with auxins in a gel (Blazich, 1988).

With production efficiency and employee safety and comfort in mind, commercial propagators may be interested in modifying auxin application processes to make them compatible with automation, lower the concentration of auxin needed for a suitable rooting response, and reduce the time that personal protective equipment must be worn during the workday.

One auxin application technique that has received little research is a foliar spray application. Although other plant growth regulators are applied as sprays under production conditions, root-promoting chemicals are not normally applied in this manner. The technique is known through verbal accounts from individuals involved in commercial propagation and from brief mention in literature, but without detailed research findings (Chadwick and Kiplinger, 1938; Hartmann et al., 2002; Kroin, 1992). A foliar application of auxin after the cuttings have been inserted has the potential of being incorporated into mechanized production processes and reducing the number of employees who must work with chemicals.

A similar technique that involves the complete immersion of cuttings has also been effective compared to a conventional basal treatment with an auxin powder (Van Bragt et al., 1976). Dipping the foliage of cuttings into an auxin-containing solution has been noted as effective for several crops (Anuradha and Sreenivasan, 1993; McGuire, 1967; McGuire and Sorenson, 1966). These techniques, however, require subsequent handling of the treated cuttings.

Exogenous auxin is capable of basipetal translocation in plant tissue (Skoog, 1938). McGuire (1967) reported that foliage and terminal buds of cuttings of 'Convexa' japanese holly (Ilex crenata) were able to absorb sufficient auxin to result in effective increases in rooting, with presence of terminal foliage required to maximize transport to the base of the cuttings. However, exogenous application of auxin can inhibit budbreak on cuttings of rose (Sun and Bassuk, 1993).

Spray adjuvants are useful in enhancing the effectiveness of foliarapplied agrichemicals. Lownds et al. (1987) demonstrated that surfactants were able to increase surface wetting and enhance penetration of NAA into foliar tissue. Nonionic organosilicone surfactants, among other types, have enhanced spray retention and reduced foliar washoff of herbicides (Reddy and Locke, 1996).

The objective of our trials was to examine the effects of a foliar spray application of the auxins IBA and NAA [as a dilution of Dip 'N Grow (Dip 'N Grow, Clackamas, Ore.)], $\mathrm{K}-\mathrm{IBA}$, and K-NAA on the rooting and subsequent shoot growth of rose cuttings. In addition, we examined the effects of addition of an organosilicone 
surfactant to the auxin spray solution and the use of multiple auxin spray applications on root and shoot growth of rose cuttings. A basal quick-dip in a common dilution of auxin served as a basis of comparison for the foliar application treatments.

\section{Materials and methods}

Cutting propagation material of 'Red Cascade' miniature rose was collected from greenhouse-grown container-grown stock plants on the campus of Auburn University (lat. $32^{\circ} 36^{\prime} \mathrm{N}$, long. $85^{\circ} 29^{\prime} \mathrm{W}$, USDA Hardiness Zone 8a) and prepared as $2-\mathrm{cm}(0.8$ inch $)$ single-node cuttings. All cuttings were inserted to a depth of $1 \mathrm{~cm}(0.4$ inch) into Fafard 3B mix (Conrad Fafard, Agawam, Mass.), a blend of peat moss, perlite, vermiculite, and pine bark, in T1204 polystyrene four-cell packs [90.13 $\mathrm{cm}^{3}\left(5.5\right.$ inch $\left.^{3}\right)$ soil volume per cell] held in L1020NCR polystyrene trays (Landmark Plastics, Akron, Ohio). Substrate was watered in advance of inserting cuttings. Cuttings in control treatments were basally quick-dipped to a depth of $0.635 \mathrm{~cm}(0.25 \mathrm{inch})$ into their respective auxin solutions for $1 \mathrm{~s}$ prior to insertion. Cuttings in all other treatments were sprayed to the drip point after insertion with their respective auxin solutions or water using a plastic, hand spray bottle. Cuttings were inserted and sprayed in the late afternoon, allowed to dry overnight on a shaded greenhouse bench, and then placed inside a $1.2 \mathrm{~m}(4 \mathrm{ft})$ wide $\times 2.4 \mathrm{~m}(8 \mathrm{ft})$ long $\times 0.9 \mathrm{~m}(3 \mathrm{ft})$ high high-humidity polyethylene-covered enclosure on top of a $7.6-\mathrm{cm}$ ( 3 inches) layer of moistened pine bark (to maintain humidity) within a double-layer, polyethylene-covered greenhouse at the Paterson Greenhouse Complex at Auburn University. Overhead mist was provided within the rooting enclosures by three Pin-Perfect $2.8-\mathrm{mm}$ orifice nozzles (Dramm Corp., Manitowoc, Wis.) spaced $0.9 \mathrm{~m}$ apart and raised 0.3 $\mathrm{m}$ (l ft) above the cuttings. Overhead mist was supplied once daily for 10 $\mathrm{s}$ at $1200 \mathrm{HR}$ to maintain a relative humidity of $95 \%$ to $100 \%$. Maximum photosynthetically active radiation in the greenhouse enclosure was 600 $\mu \mathrm{mol} \cdot \mathrm{m}^{-2} \cdot \mathrm{s}^{-1}$ and daily maximum/ minimum temperature was $27 \pm 6^{\circ} \mathrm{C}$ $\left(80.6 \pm 10.8^{\circ} \mathrm{F}\right) / 18 \pm 3{ }^{\circ} \mathrm{C}(64.4 \pm$ $\left.5.4^{\circ} \mathrm{F}\right)$.

A completely randomized design was utilized in all experiments for assignment of treatments to experimental units. All cuttings were evaluated for rooting percentage, total root length, percentage of rooted cuttings with shoot growth, and shoot length at the end of their respective rooting periods. Least squares means were calculated for root length and shoot length using rooted cuttings only. Regression analysis was used to examine responses to increasing auxin concentration in the spray treatments using a linear model and a log-logistic model. The log-logistic model (Seefeldt et al., 1995) was indicated for decreasing, sigmoidal response curves. Dunnett's test (one-tailed) was used to compare spray treatments with the basal quickdip control treatment. In addition, a factorial analysis was carried out on the foliar spray treatments in Expts. 3 and 5. Statistical analysis was conducted utilizing the SAS System, Release 8.2 (SAS Institute, Cary, N.C.).

EXPT. 1. Cuttings in the control treatment were quick-dipped in a solution of Dip 'N Grow diluted with water to $4920.4 \mu \mathrm{M}\left(1000 \mathrm{mg} \cdot \mathrm{L}^{-1}\right)$ $\mathrm{IBA}+2685.2 \mu \mathrm{M}\left(500 \mathrm{mg} \cdot \mathrm{L}^{-1}\right) \mathrm{NAA}$. Cuttings in all other treatments were sprayed with Dip 'N Grow diluted with water to concentrations ranging from 0 to $246 \mu \mathrm{M}\left(50 \mathrm{mg} \cdot \mathrm{L}^{-1}\right) \mathrm{IBA}+$ 134.3 м $\left(25 \mathrm{mg} \cdot \mathrm{L}^{-1}\right)$ NAA (Table 1). Forty cuttings per treatment were prepared on 1 June 2001 and evaluated after $23 \mathrm{~d}$.

Table 1. Rooting and initial shoot growth on single-node cuttings of 'Red Cascade' miniature rose ${ }^{\mathrm{z}}$ in response to Dip 'N Grow ${ }^{\mathrm{y}}$ applied as a basal quick-dip (prior to insertion into the rooting substrate) or a single foliar spray applied to the drip point (after insertion) (Expt. 1).

\begin{tabular}{lccccc}
\hline Application & $\begin{array}{c}\text { Rate of } \\
\text { IBA + NAA } \\
\text { method }\end{array}$ & $\begin{array}{c}\text { Rooting } \\
(\boldsymbol{\mu})\end{array}$ & $\begin{array}{c}\text { Total root } \\
\text { length/ } \\
\text { cutting } \\
(\mathbf{m m})^{\mathrm{w}}\end{array}$ & $\begin{array}{c}\text { Cuttings } \\
\text { with } \\
\text { shoots } \\
(\%)\end{array}$ & $\begin{array}{c}\text { Shoot } \\
\text { length/ } \\
\text { cutting } \\
(\mathbf{m m})^{\mathrm{w}}\end{array}$ \\
\hline Basal quick-dip & $4920.4+2685.2$ & 100.0 & 238 & 95.0 & 23.7 \\
Foliar spray & $0+0$ & 95.0 & $116 \mathrm{a}$ & 100.0 & 15.6 \\
& $2.46+1.343$ & 100.0 & $139 \mathrm{a}$ & 92.5 & 23.2 \\
& $4.9+2.69$ & 97.5 & $132 \mathrm{a}$ & 94.4 & 21.9 \\
& $12.30+6.713$ & 100.0 & $139 \mathrm{a}$ & 100.0 & 18.5 \\
& $24.6+13.43$ & 100.0 & $143 \mathrm{a}$ & 97.5 & 22.7 \\
& $49.2+26.9$ & 92.5 & $141 \mathrm{a}$ & 92.5 & 17.0 \\
& $246.0+134.3$ & $62.5 \mathrm{a}^{\mathrm{v}}$ & $139 \mathrm{a}$ & $27.9 \mathrm{a}$ & $3.0 \mathrm{a}$ \\
& Significance & $\mathrm{G}^{* * *}$ & $\mathrm{NS}$ & $\mathrm{G}^{* * *}$ & $\mathrm{G}^{* * *}$ \\
\hline
\end{tabular}

${ }^{\mathrm{z}} 2-\mathrm{cm}(0.8$ inch $)$ cuttings were inserted to a depth of $1 \mathrm{~cm}(0.4$ inch $)$ into pre-moistened Fafard $3 \mathrm{~B}$ mix and evaluated for rooting and shoot development after $23 \mathrm{~d}$.

yndole-3-butyric acid (IBA) + 1-naphthaleneacetic acid (NAA)

'IBA: $4.9 \mu \mathrm{M}=1 \mathrm{mg} \cdot \mathrm{L}^{-1}(\mathrm{ppm})$; NAA: $5.4 \mu \mathrm{M}=1 \mathrm{mg} \cdot \mathrm{L}^{-1}$

"Least squares means calculated using rooted cuttings only; $25.4 \mathrm{~mm}=1$ inch.

"Means followed by "a" within a column are significantly less than the mean for the basal quick-dip treatment according to Dunnett's test (lower-tailed test); $P \leq 0.05$.

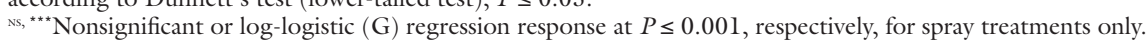


Table 2. Rooting and initial shoot growth on single-node cuttings of 'Red Cascade' miniature rose ${ }^{z}$ in response to $\mathrm{K}-\mathrm{IBA}^{\mathrm{y}}$ applied as a basal quick-dip (prior to insertion into the rooting substrate) or a single foliar spray applied to the drip point (after insertion) (Expt. 2).

\begin{tabular}{lccccc}
\hline $\begin{array}{l}\text { Application } \\
\text { method }\end{array}$ & $\begin{array}{c}\text { Rate } \\
(\boldsymbol{\mu M})^{\mathrm{x}}\end{array}$ & $\begin{array}{c}\text { Rooting } \\
(\%)\end{array}$ & $\begin{array}{c}\text { Total root } \\
\text { length/ } \\
\text { cutting }(\mathbf{m m})^{\mathrm{w}}\end{array}$ & $\begin{array}{c}\text { Cuttings } \\
\text { with } \\
\text { shoots }(\%)\end{array}$ & $\begin{array}{c}\text { Shoot } \\
\text { length/ } \\
\text { cutting }(\mathbf{m m})^{\mathrm{w}}\end{array}$ \\
\hline Basal quick-dip & 4144.2 & 100.0 & 213 & 100.0 & 29.5 \\
Foliar spray & 0 & 95.0 & $149 \mathrm{a}^{\mathrm{v}}$ & 89.4 & 26.0 \\
& 2.07 & 95.0 & $167 \mathrm{a}$ & 100.0 & 23.5 \\
& 4.1 & 97.5 & $132 \mathrm{a}$ & 89.4 & 21.3 \\
& 10.36 & 95.0 & $103 \mathrm{a}$ & 94.7 & $19.1 \mathrm{a}$ \\
& 20.7 & 100.0 & $133 \mathrm{a}$ & 97.5 & 23.8 \\
& 41.4 & 95.0 & $120 \mathrm{a}$ & 97.2 & 21.8 \\
& 207.2 & 100.0 & $169 \mathrm{a}$ & 97.5 & 27.8 \\
\multicolumn{2}{c}{ Significance } & NS & NS & NS & NS \\
\hline
\end{tabular}

${ }^{\mathrm{z}} 2-\mathrm{cm}(0.8$ inch $)$ cuttings were inserted to a depth of $1 \mathrm{~cm}(0.4 \mathrm{inch})$ into pre-moistened Fafard $3 \mathrm{~B}$ mix and evaluated for rooting and shoot development after $23 \mathrm{~d}$.

y Potassium salt of indole-3-butyric acid.

x $4.1 \mu \mathrm{M}=1 \mathrm{mg} \cdot \mathrm{L}^{-1}(\mathrm{ppm})$.

"Least squares means calculated using rooted cuttings only; $25.4 \mathrm{~mm}=1$ inch.

"Means followed by "a" within a column are significantly less than the mean for the basal quick-dip treatment according to Dunnett's test (lower-tailed test); $P \leq 0.05$.

${ }^{\mathrm{N}}$ Nonsignificant regression response for spray treatments only.

Co.). Cuttings in all other treatments were sprayed with aqueous solutions of K-NAA at concentrations ranging from 0 to $222.9 \mu \mathrm{M}\left(50 \mathrm{mg} \cdot \mathrm{L}^{-1}\right)$ plus $1.0 \mathrm{~mL} \cdot \mathrm{L}^{-1}$ Kinetic surfactant (Table 4). Thirty cuttings per treatment were prepared on 24 May 2002 and evaluated after $24 \mathrm{~d}$.

EXPT. 5. Cuttings in the control treatment were quick-dipped in a solution of Dip 'N Grow diluted with water to $4920.4 \mu \mathrm{M}\left(1000 \mathrm{mg} \cdot \mathrm{L}^{-1}\right) \mathrm{IBA}$ $+2685.2 \mu \mathrm{m}\left(500 \mathrm{mg} \cdot \mathrm{L}^{-1}\right) \mathrm{NAA}$. Cuttings in a second treatment received no auxin application. Cuttings in all other treatments were sprayed daily with Dip 'N Grow diluted with water at either $4.9 \mu \mathrm{M}\left(1 \mathrm{mg} \cdot \mathrm{L}^{-1}\right) \mathrm{IBA}+2.69 \mu \mathrm{M}(0.5$ $\left.\mathrm{mg} \cdot \mathrm{L}^{-1}\right) \mathrm{NAA}$ or $24.6 \mu \mathrm{m}\left(5 \mathrm{mg} \cdot \mathrm{L}^{-1}\right)$ IBA $+13.43 \mu \mathrm{M}\left(2.5 \mathrm{mg} \cdot \mathrm{L}^{-1}\right)$ NAA plus $1.0 \mathrm{~mL} \cdot \mathrm{L}^{-1}$ Kinetic surfactant for 1,3 , 5 , or 7 consecutive days (beginning the day the cuttings were inserted) as a 2 $\times 4$ factorial arrangement (two rates of auxin each applied daily for the four durations). Overhead mist was not applied to the cuttings in the highhumidity enclosure until the eighth day of the experiment. Thirty cuttings per treatment were prepared on 27 Mar. 2002 and evaluated after $31 \mathrm{~d}$.

\section{Results and discussion}

ExPT. 1. Rooting percentage and percent of rooted cuttings with shoots remained steady at lower auxin rates using Dip 'N Grow as a foliar spray, followed by a decline at the higher rates (Table 1). Rooting percentages were lower than the basal quick-dip control on cuttings sprayed with the highest concentration of Dip 'N Grow, but were similar for all other concentrations. The basal quick-dip produced greater total root length than did the spray treatments, suggesting that the foliar-applied auxin was not absorbed and/or translocated sufficiently to the base of the cuttings. Shoot length on cuttings sprayed with all except the highest rate of auxin was similar to control (basally quick-dipped) cuttings. A log-logistic model was suggested by decreasing, sigmoidal dose-response curves with increasing auxin concentration for rooting percentage, percentage of rooted cuttings with shoots, and total shoot length; the model was found to be highly significant in all three cases. While auxin was not necessary for rooting, a basal quick-dip in auxin promoted early establishment of a larger root system on the cuttings.

ExPT. 2. Rooting percentage and percent of rooted cuttings with shoots remained fairly steady at all rates of K-IBA applied as a foliar spray, and were similar to the basal quick-dip control (Table 2). The basal quick-dip produced greater total root length than did the spray treatments, suggesting that the foliar-applied auxin was not absorbed and/or translocated sufficiently to the base of the cuttings (as was also noted with IBA + NAA in Expt. 1). Shoot length on sprayed cuttings was similar to control (basally quick-dipped) cuttings with all spray treatments. While K-IBA was not necessary for rooting, a basal quickdip promoted early establishment of a larger root system on the cuttings, as did IBA + NAA in Expt 1 .

Expт. 3. Overall root and shoot development was similar or better on cuttings treated with the basal quickdip than on sprayed cuttings (Table 3 ). As in Expt. 1, decreasing, sigmoidal dose-response curves with increasing auxin concentration (both with and without surfactant) were indicated by the data for the rooting and shoot growth variables, with log logistic models being notably significant in all but one case. Also, as in Expt. 1, rooting percentage, percent of rooted cuttings with shoots, and shoot length were significantly lower at the highest rates of auxin applied as a foliar spray compared to a basal quick-dip. However, total root length and shoot length were greater when Kinetic surfactant was included in the spray solutions, than when not, suggesting that the surfactant was effective in enhancing auxin uptake from the spray solutions. Interaction between factors resulted in a decrease in rooting percentage beginning at a lower rate of auxin when surfactant was not included in the spray solutions compared to its inclusion.

Other adjuvants were also tested with foliar applications of auxin on 'Red Cascade' miniature rose cuttings in our studies (data not presented). Chem-Stik (nonionic emulsifiable polyethylene spreader-sticker) at 0.5 $\mathrm{mL} \cdot \mathrm{L}^{-1}$ (500 ppm), Speed (nonionic organosiloxane blend) at $1.0 \mathrm{~mL} \cdot \mathrm{L}^{-1}$, and PX-XPN2 (experimental cationic modified fatty amine polymer) at $1.0 \mathrm{~mL} \cdot \mathrm{L}^{-1}$ (Precision Laboratories, Northbrook, Ill.) all produced results similar to Kinetic.

Expт. 4. All cuttings rooted and produced new shoots using the basal quick-dip control treatment and all foliar spray treatments (Table $4)$. Total root length was greater on cuttings receiving the basal quick-dip than in any of the foliar spray treatments, again suggesting insufficient absorption and/or translocation of the foliar-applied auxin to the cutting base. No or low concentrations of K-NAA applied as a foliar spray produced shoot length greater than the basal quick-dip in K-NAA, suggesting that the amount of auxin taken up with the 
Table 3. Rooting and initial shoot growth on single-node cuttings of 'Red Cascade' miniature rose ${ }^{\mathrm{z}}$ in response to Dip 'N Grow ${ }^{\mathrm{y}}$ applied as a basal quickdip (prior to insertion into the rooting substrate) or a single foliar spray with and without $1.0 \mathrm{~mL} \cdot \mathrm{L}^{-1}(1000 \mathrm{ppm})$ Kinetic surfactant applied to the drip point (after insertion) (Expt. 3).

\begin{tabular}{|c|c|c|c|c|}
\hline $\begin{array}{l}\text { Rate of IBA } \\
+ \text { NAA }(\mu M)^{x}\end{array}$ & $\begin{array}{l}\text { Rooting } \\
(\%)\end{array}$ & $\begin{array}{c}\text { Total root } \\
\text { length } / \\
\text { cutting }(\mathrm{mm})^{\mathrm{w}}\end{array}$ & $\begin{array}{l}\text { Cuttings } \\
\text { with } \\
\text { shoots (\%) }\end{array}$ & $\begin{array}{c}\text { Shoot } \\
\text { length } / \\
\text { cutting }(\mathrm{mm})^{\mathrm{w}}\end{array}$ \\
\hline \multicolumn{5}{|c|}{ Basal quick-dip } \\
\hline $4920.4+2685.2$ & 100.0 & 392.6 & $93.3 \%$ & 29.5 \\
\hline \multicolumn{5}{|c|}{ Foliar spray without Kinetic surfactant } \\
\hline $0+0$ & 83.3 & $121 \mathrm{a}$ & 100.0 & 20.9 \\
\hline $0.49+0.269$ & 96.7 & $104 \mathrm{a}$ & 100.0 & 15.0 \\
\hline $2.46+1.343$ & 90.0 & $117 \mathrm{a}$ & 95.8 & 20.8 \\
\hline $4.9+2.69$ & 86.7 & $147 \mathrm{a}$ & 100.0 & 17.1 \\
\hline $24.6+13.43$ & 90.0 & $132 \mathrm{a}$ & 100.0 & 22.4 \\
\hline $49.2+26.9$ & 96.7 & $155 \mathrm{a}$ & 96.3 & $12.2 \mathrm{a}$ \\
\hline $123.0+67.13$ & $70.0 \mathrm{a}^{\mathrm{v}}$ & $65 \mathrm{a}$ & 73.8 & $3.5 \mathrm{a}$ \\
\hline $246.0+134.3$ & $40.0 \mathrm{a}$ & 69 a & $44.4 \mathrm{a}$ & $1.6 \mathrm{a}$ \\
\hline Significance & $\mathrm{G}^{\star \star *}$ & $\mathrm{G}^{* *}$ & $\mathrm{G}^{\star \star *}$ & $\mathrm{G}^{* \star *}$ \\
\hline \multicolumn{5}{|c|}{ Foliar spray with $1.0 \mathrm{~mL} \cdot \mathrm{L}^{-1}$ Kinetic surfactant } \\
\hline $0+0$ & 90.0 & $136 \mathrm{a}$ & 100.0 & 23.0 \\
\hline $0.49+0.269$ & 96.7 & $139 \mathrm{a}$ & 96.3 & 21.3 \\
\hline $2.46+1.343$ & 96.7 & $167 \mathrm{a}$ & 96.7 & 26.4 \\
\hline $4.9+2.69$ & 96.7 & $208 \mathrm{a}$ & 100.0 & 33.1 \\
\hline $24.6+13.43$ & 86.7 & $133 \mathrm{a}$ & 100.0 & 27.0 \\
\hline $49.2+26.9$ & 96.7 & $150 \mathrm{a}$ & 100.0 & 19.3 \\
\hline $123.0+67.13$ & 96.7 & $131 \mathrm{a}$ & 93.3 & 19.4 \\
\hline $246.0+134.3$ & $70.0 \mathrm{a}$ & 79 a & $52.5 \mathrm{a}$ & $4.2 \mathrm{a}$ \\
\hline Significance & $\mathrm{G}^{* *}$ & NS & $\mathrm{G}^{* * *}$ & $\mathrm{G}^{* *}$ \\
\hline \multicolumn{5}{|c|}{ Foliar spray application: } \\
\hline Auxin rate & $0.0001^{\mathrm{u}}$ & 0.0001 & 0.0001 & 0.0001 \\
\hline Surfactant & 0.5061 & 0.0038 & 0.2372 & 0.0001 \\
\hline Auxin rate & & & & \\
\hline$\times$ surfactant & 0.0093 & NS & NS & NS \\
\hline
\end{tabular}

${ }^{\mathrm{z}} 2-\mathrm{cm}(0.8$ inch $)$ cuttings were inserted to a depth of $1 \mathrm{~cm}(0.4$ inch $)$ into pre-moistened Fafard $3 \mathrm{~B}$ mix and evaluated for rooting and shoot development after $33 \mathrm{~d}$.

yndole-3-butyric acid (IBA) + 1-naphthaleneacetic acid (NAA).

IBA: $4.9 \mu \mathrm{M}=1 \mathrm{mg} \cdot \mathrm{L}^{-1}(\mathrm{ppm})$; NAA: $5.4 \mu \mathrm{M}=1 \mathrm{mg} \cdot \mathrm{L}^{-1}$.

"Least squares means calculated using rooted cuttings only; $25.4 \mathrm{~mm}=1$ inch.

"Means followed by "a" within a column are significantly less than the mean for the basal quick-dip treatment according to Dunnett's test (lower-tailed test); $P \leq 0.05$

${ }^{u} P$ values for main effects and interaction. If the interaction was determined to be nonsignificant (ns), $P$ values are reported for the main effects only.

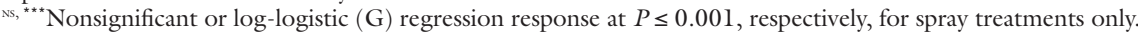

basal quick-dip was sufficient to reduce initial shoot growth. K-NAA as a basal quick-dip appears to be highly effective for promoting greater total root length for this cultivar. While auxin was not necessary for rooting, establishment of a larger root system on the cuttings was promoted with the use of a basal quick-dip.

EXPT. 5. Rooting percentage and percent cuttings with shoots exhibited no trend in response to increasing number of spray applications at either auxin concentration, while total root length and shoot length showed a decreasing trend in response to increasing number of spray applications at the higher of the two auxin rates (Table
5). Results indicate that multiple spray applications of Dip 'N Grow do not enhance root and shoot development over a single application, and may even be detrimental.

\section{Conclusion}

Results suggest that auxin applied to the foliage of cuttings of 'Red Cascade' miniature rose can produce rooting percentages similar to a basal quick-dip, provided that the auxin concentration in the spray solution is not too high. Lesser total root length on untreated cuttings and cuttings sprayed with auxin suggests that foliarapplied auxin does not penetrate the leaf tissue and translocate to the site of root initiation to a sufficient degree to stimulate adventitious rooting to the same extent as a basal quick-dip application. However, total root length and shoot length in response to foliar applications of auxin were enhanced by the use of a surfactant, indicating that use of surfactant can be beneficial. In addition, higher rates of auxin applied as a foliar spray can have a negative effect on root and shoot development.

Auxin application by either a basal quick-dip or a foliar spray was not an absolute requirement for rooting cuttings of 'Red Cascade' miniature rose in this study. Use of propagation material of a lesser quality could have produced different results.

The actual process of applying auxin to the foliage of cuttings via a foliar spray involved no particular requirements beyond those typically involved in the application of other growth regulators. Under nursery production conditions, the technique could have allowed one trained applicator to perform a foliar application with conventional spray equipment in less time than would have been required for several workers to perform a manual quick-dip on the same quantity of individual cuttings, permitting the use of lower chemical rates and reducing the number of employees required for application.

General reports point to use of foliar applications of auxin in nursery practice and have indicated its applicability with selected crops (Hartmann et al., 2002; Kroin, 1992); however, lack of detailed findings makes it difficult to compare results with those of the present study. Chadwick and Kiplinger (1938) reported that a basal soak in a dilute auxin solution was more effective than a foliar spray application for chrysanthemum cuttings; however, the dilute soaking method has been replaced in modern nursery practice by the basal quick-dip method using concentrated auxin solutions and basal application of powder formulations.

Cuttings of some other ornamental species have responded as well to a foliar application of auxin as to a basal quick-dip in our trials, while the standard basal quick-dip continues to be preferable with many other species (Blythe et al., 2003). Examination of other factors that influence absorption and translocation of foliar-applied auxin to the site of rooting may be worthwhile for future research. 
Table 4. Rooting and initial shoot growth on single-node cuttings of 'Red Cascade' miniature rose $\mathrm{e}^{\mathrm{z}}$ in response to $\mathrm{K}-\mathrm{NAA}^{\mathrm{y}}$ applied as a basal quick-dip (prior to insertion into the rooting substrate) or a single foliar spray with $1.0 \mathrm{~mL} \cdot \mathrm{L}^{-1}$ (1000 ppm) Kinetic surfactant applied to the drip point (after insertion) (Expt. 4).

\begin{tabular}{|c|c|c|c|c|c|}
\hline $\begin{array}{l}\text { Application } \\
\text { method }\end{array}$ & $\begin{array}{l}\text { Rate } \\
(\mu M)^{x}\end{array}$ & $\begin{array}{c}\text { Rooting } \\
(\%)\end{array}$ & $\begin{array}{c}\text { Total root } \\
\text { length } / \\
\text { cutting }(\mathrm{mm})^{\mathrm{w}}\end{array}$ & $\begin{array}{l}\text { Cuttings } \\
\text { with } \\
\text { shoots (\%) }\end{array}$ & $\begin{array}{c}\text { Shoot } \\
\text { length/ } \\
\text { cutting }(\mathrm{mm})^{\mathrm{w}}\end{array}$ \\
\hline Basal quick-dip & 4458.3 & 100.0 & 702 & 100.0 & 53.7 \\
\hline \multirow[t]{8}{*}{ Foliar spray } & 0 & 100.0 & $351 a^{v}$ & 100.0 & $82.0 \mathrm{~b}$ \\
\hline & 0.45 & 100.0 & $292 \mathrm{a}$ & 100.0 & $77.1 \mathrm{~b}$ \\
\hline & 2.23 & 100.0 & $264 \mathrm{a}$ & 100.0 & $74.9 \mathrm{~b}$ \\
\hline & 4.5 & 100.0 & $329 a$ & 100.0 & 70.1 \\
\hline & 22.3 & 100.0 & $251 \mathrm{a}$ & 100.0 & 66.7 \\
\hline & 44.6 & 100.0 & $276 \mathrm{a}$ & 100.0 & 65.5 \\
\hline & 111.5 & 100.0 & $229 a$ & 100.0 & 59.1 \\
\hline & 222.9 & 100.0 & $242 \mathrm{a}$ & 100.0 & 48.2 \\
\hline \multicolumn{2}{|c|}{ Significance } & NS & $\mathrm{L}^{* *}$ & NS & $\mathrm{L}^{* * *}$ \\
\hline
\end{tabular}

${ }^{2} 2-\mathrm{cm}(0.8$ inch $)$ cuttings were inserted to a depth of $1 \mathrm{~cm}(0.4 \mathrm{inch})$ into pre-moistened Fafard $3 \mathrm{~B}$ mix and evaluated for rooting and shoot development after $24 \mathrm{~d}$.

yotassium salt of 1 -naphthaleneacetic acid.

${ }^{\mathrm{x}} 4.5 \mathrm{uM}=1 \mathrm{mg} \cdot \mathrm{L}^{-1}(\mathrm{ppm})$

w $25.4 \mathrm{~mm}=1$ inch

"Means followed by "a" or "b" within a column are significantly less or greater, respectively, than the mean for the basal quick-dip treatment according to Dunnett's test (one-tailed test); $P \leq 0.05$.

Ns, ${ }^{* *,{ }^{* *}}$ Nonsignificant or significant at $P \leq 0.01$ or 0.001 , respectively, for spray treatments only; $\mathrm{L}=$ linear regression response.

Table 5. Rooting and initial shoot growth on single-node cuttings of 'Red Cascade' miniature rose ${ }^{\mathrm{z}}$ in response to Dip 'N Grow' applied as a basal quick-dip (prior to insertion into the rooting substrate), single and multiple foliar sprays with $1.0 \mathrm{~mL} \cdot \mathrm{L}^{-1}(1000 \mathrm{ppm})$ Kinetic surfactant applied to the drip point, or no auxin treatment (Expt. 5).

\begin{tabular}{|c|c|c|c|c|}
\hline $\begin{array}{l}\text { No. of } \\
\text { applications }\end{array}$ & $\begin{array}{c}\text { Rooting } \\
(\%)\end{array}$ & $\begin{array}{c}\text { Total root } \\
\text { length } / \\
\text { cutting }(\mathrm{mm})^{\mathrm{w}}\end{array}$ & $\begin{array}{c}\text { Cuttings } \\
\text { with } \\
\text { shoots (\%) }\end{array}$ & $\begin{array}{c}\text { Shoot length/ } \\
\text { cutting } \\
(\mathrm{mm})^{\mathrm{w}}\end{array}$ \\
\hline \multicolumn{5}{|c|}{ Basal quick-dip with Dip 'N Grow (4920.4 $\left.\mu_{M} I B A+2685.2 \mu_{M} N A A^{\mathrm{x}}\right)$} \\
\hline 1 & 100.0 & 314 & 96.7 & 60.5 \\
\hline \multicolumn{5}{|c|}{ No auxin treatment } \\
\hline 0 & 100.0 & 227 & 100.0 & 68.2 \\
\hline \multicolumn{5}{|c|}{ Foliar spray with Dip 'N Grow $(4.9 \mu M I B A+2.69 \mu M N A A)$} \\
\hline 1 & 96.7 & 234 & 100.0 & 68.6 \\
\hline 3 & 100.0 & 252 & 100.0 & 71.0 \\
\hline 5 & 93.3 & $167 \mathrm{a}^{\mathrm{y}}$ & 100.0 & 51.0 \\
\hline 7 & 100.0 & $207 \mathrm{a}$ & 100.0 & 65.6 \\
\hline Significance & NS & NS & NS & NS \\
\hline \multicolumn{5}{|c|}{ Foliar spray with Dip 'N Grow (24.6 $\mu M I B A+13.43 \mu M N A A)$} \\
\hline 1 & 93.3 & 213 & 100.0 & 62.2 \\
\hline 3 & 100.0 & $150 \mathrm{a}$ & 100.0 & 56.0 \\
\hline 5 & 96.7 & $148 \mathrm{a}$ & 100.0 & 49.2 \\
\hline 7 & 86.7 & $108 \mathrm{a}$ & 96.3 & 38.0 \\
\hline Significance & NS & $\mathrm{L}^{* * *}$ & NS & $\mathrm{L}^{* * *}$ \\
\hline \multicolumn{5}{|l|}{ Foliar spray application: } \\
\hline No. of applications & $0.2572^{\mathrm{u}}$ & 0.7160 & 0.2510 & 0.6895 \\
\hline Auxin rate & 0.7740 & 0.0014 & 0.0364 & 0.1207 \\
\hline Applications & & & & \\
\hline$\times$ auxin rate & NS & 0.0001 & NS & 0.0001 \\
\hline
\end{tabular}

${ }^{2} 2-\mathrm{cm}(0.8 \mathrm{inch})$ cuttings were inserted to a depth of $1 \mathrm{~cm}(0.4 \mathrm{inch})$ into pre-moistened Fafard $3 \mathrm{~B}$ mix and evaluated for rooting and shoot development after $31 \mathrm{~d}$

Indole-3-butyric acid (IBA) + 1-naphthaleneacetic acid (NAA)

IBA: $4.9 \mu \mathrm{M}=1 \mathrm{mg} \cdot \mathrm{L}^{-1}(\mathrm{ppm})$; NAA: $5.4 \mu \mathrm{M}=1 \mathrm{mg} \cdot \mathrm{L}^{-1}$

wLeast squares means calculated using rooted cuttings only; $25.4 \mathrm{~mm}=1$ inch.

"Means followed by "a" within a column and auxin rate are significantly less than the mean for the basal quick-dip treatment according to Dunnett's test (lower-tailed test); $P \leq 0.05$.

${ }^{u} P$ values for main effects and interaction. If the interaction was determined to be nonsignificant (Ns), $P$ values are reported for the main effects only.

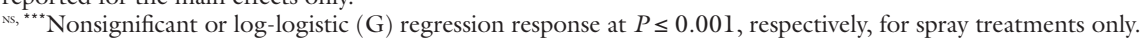

\section{Literature cited}

Anuradha, K. and M.S. Sreenivasan. 1993. Studies on rooting ability of Couvery (Catimor) cuttings. J. Coffee Res. 23:55-58.

Blazich, F.A. 1988. Chemicals and formulations used to promote adventitious rooting, p. 132-149. In: T.E. Davis, B.E. Haissig, and N. Sankhla (eds.). Adventitious root formation in cuttings. Dioscorides Press, Portland, Ore

Blythe, E.K., J.L. Sibley, K.M. Tilt, and J.M. Ruter. 2003. Foliar application of auxin for rooting cuttings of ornamental crops. J. Environ. Hort. 21:131-136.

Chadwick, L.C. and D.C. Kiplinger. 1938. The effect of synthetic growth substances on the rooting and subsequent growth of ornamental plants. Proc. Amer. Soc. Hort. Sci. 36:809-816.

Hartmann, H.T., D.E. Kester, F.T. Davies, Jr., and R.L. Geneve. 2002. Hartmann and Kester's plant propagation: Principles and practices, 7 th ed. Prentice Hall, Upper Saddle River, N.J.

Kroin, J. 1992. Advances using indole-3-butyric acid (IBA) dissolved in water for rooting cuttings, transplanting, and grafting. Comb. Proc. Intl. Plant Prop. Soc. 42:489-492.

Lownds, N.K., J.M. Leon, and M.J. Bukovac. 1987. Effect of surfactants on foliar penetration of NAA and NAA-induced ethylene evolution in cowpea. J. Amer. Soc. Hort. Sci. 112:554-560.

McGuire, J.J. 1967. Entrance of synthetic growth regulator IAA-2-14C into cuttings of Ilex crenata 'Convexa'. Comb. Proc. Intl. Plant Prop. Soc. 17:322-327.

McGuire, J.J. and D.C. Sorenson. 1966. Effect of terminal applications of IBA on rooting of woody ornamental plants. Comb. Proc. Intl. Plant Prop. Soc. 16: 257-290.

Reddy, K.N. and M.A. Locke. 1996. Imazaquin spray retention, foliar washoff and runoff losses under simulated rainfall. Pesticide Sci. 48:179-187.

Seefeldt, S.S., J.E. Jensen, and E.P. Fuerst. 1995. Log-logistic analysis of herbicide dose-response relationships. Weed Technol. 9:218-227.

Skoog, F. 1938. Absorption and translocation of auxin. Amer. J. Bot. 25:361-372.

Sun, W.Q. and N.L. Bassuk. 1993. Auxininduced ethylene synthesis during rooting and inhibition of budbreak of 'Royalty' rose cuttings. J. Amer. Soc. Hort. Sci. 118:638643 .

Van Bragt, J., H. Van Gelder, and R.L.M. Pierik. 1976. Rooting of shoot cuttings of ornamental shrubs after immersion in auxin-containing solutions. Scientia Hort. 4:91-94. 